\title{
Interpretation issues in the polyphonic repertoire of the students from musical performance classes in the universities
}

\author{
Diana Stancheva \\ Department of Music, Plovdiv University “P. Hilendarsky”, Plovdiv, Bulgaria
}

Email address:

diahanouse@abv.bg

\section{To cite this article:}

Diana Stancheva. Interpretation Issues in the Polyphonic Repertoire of the Students from Musical Performance Classes in the Universities. International Journal of Literature and Arts. Special Issue: Musical Theory, Psychology and Pedagogy. Vol. 2, No. 5-1, 2014, pp. 70-76. doi: 10.11648/j.ijla.s.2014020501.22

\begin{abstract}
The study is oriented towards one of the most disputable, and least explored and clarified up to now issues in the methodology of teaching the accordion and in the theory of the performing art, namely - the position of the accordionist regarding the selection of means of expression, in his capacity of an interpreter of adapted (not original) pieces - of which consist the most part of the polyphonic works of the repertoire of the students from performance classes in the Universities. The focus is placed on the major and basic issue of performance of polyphonic music, related to the specifics of sound-forming and sound-shaping with the accordion, namely: how should the theme be outlined in a distinct manner, how should a certain motive be emphasized or how should a particular voice stand out in the polyphonic texture, provided the air-flow is being directed equally to all open resonator valves. Two opposite concepts of articulation are presented - both being incorporated in the practice of performance and teaching of the accordionists - the dispute between which still remains open. By analyzing the strengths and weaknesses of these concepts, an attempt is made to extend and deepen the knowledge towards finding an adequate solution to the problem of the solo interpretation of polyphonic transcription with the means of expression of the accordion. The issues described that are placed theoretically for the first time in Bulgaria provide guidelines for certain future more detailed and extensive research in the field of methodology of teaching the accordion and the accordion performance art.
\end{abstract}

Keywords: Accordion, Performance, Transcriptions, Polyphony, Methodology, Articulation

\section{Introduction}

Long has been the way of polyphonic thinking until its settlement in the artistic practice with its full variety of specific characteristics and trends of development. Starting with the first samples of polyphonic characteristics, dating the IX - X centuries, throughout its two eras of flourish (XV - XVI centuries, peaked by the works of Palestrina and Orlande de Lassus, and XVII - XVIII - with the works of Bach and Handel) up to present times, it has never lost its value and significance. From Mozart and Beethoven, Brahms and Tchaikovsky to Hindemith and Shostakovich, the potential of polyphonic structure has always, in practice, justified the interest towards it. In a broad sense, for the performer there is no musical piece, in which the question of distinctly outlining the collage of the different musical layers and elements of the texture, is not relevant to the performance of multiple voices. But here we will concentrate mainly on the work upon "pure" polyphony, and will not treat the homophonic and harmonic works.

And since throughout the time period, in which that same polyphony had been developing quite rapidly and had produced its masterpieces, the accordion had not been invented yet, today the accordion player learns how to think in a polyphonic manner mainly by the interpretation of those works in the form of transcriptions.

Those are mainly clavier and organ works of Bach, as well as some other works of the old masters, originally written for those instruments. With those works the accordionist is given the difficult task not only to know the characteristic features of the leading-voice polyphony, the contrasting polyphony and the imitational polyphony with their specifics and differences of meaning, but, while solving the problems of the type of polyphony, to hold a 
certain position on the choice of expressions in the interpretation of a non-original piece - this being the most disputable, the least explored and the least clarified point for the teacher, the performer and the music theorist.

\section{Subject, Purpose and Objectives}

The method used in the theoretical exploitation of the particularities when working with polyphonic works in instrumental methodology in general is the following:

1. Brief description of the characteristic features of the leading-voice polyphony, the contrasting polyphony and the imitational polyphony, which the teacher should bear in mind and to which the performer should be introduced.

2. Directions on how to actually work with the student, so that he or she is able to learn how to discover, hear and re-create those particularities in a correct manner.

The questions, arising form point 1 have been developed and summarized many times by theoretical musicology. They are taught in the polyphony classes and the classes of musical analysis, generalized in the clavier methodologies, that is why the current study will not dwell on them.

The particular practical working directions (point 2) can be derived by the accordionists mainly from the clavier methodology. That particular part of those directions, which treats the methods of development of the polyphonic hearing when working with the instrument, is applicable to accordion teaching as well. The rest, however, cannot be used by the teachers and the accordion performers, since they provide concrete ways of overcoming the specifics of the polyphonic style with the means of expression of an instrument, which has nothing in common with ours (except for a few external similarities).

For example, it is known that "the main task of the performer in the leading-voice polyphony is to lead the main voice in a distinct and dominant manner, and to ensure that the complementary voices are not opposed to it, but are embracing the leading line in a melodious manner" „при подгласната полифония главната задача на изпълнителя е основният глас да се води изявено, доминиращо, допълващите гласове да не се противопоставят по звучене, а напевно да обвиват водещата мелодия" [12, p. 68]. But how should this be achieved is a question, which the pianists relate to the usage of pure clavier means of expression, typical for a sound-formation which is foreign to the nature of the accordion.

The concrete tasks which have been developed and summarized many times in theoretical musicology and which the leading-voice polyphony, the contrasting polyphony and the imitational polyphony set before the performer, depending on their particular specifics, as well as the popular ways in clavier methodology for activation of the polyphonic hearing of the students while interpreting polyphonic works, will not be covered by this study.

The purpose of this study is to make an attempt to find an adequate solution of the issues of the solo interpretation of polyphonic transcriptions with the accordion means of expression. That is why the accent will be put to the major and basic issue when playing polyphonic music, related to the specifics of the sound-formation and sound-shaping with the accordion, namely: how should the theme be outlined in a distinct manner, how should a certain motive be emphasized or how should a particular voice stand out, in other words - how to separate the "main" in the polyphonic texture, provided the air-flow is being directed equally to all open resonator valves.

When the music texture is distributed in such a way that the "main" (which has to stand out) is performed independently in a certain manual, there is practically no issue at all. The same is with the polyphonic diphthong in which each voice is performed over a different manual. In such cases the performer relies on the natural stereophonic effect, obtained by the unfolding of the two corps of the accordion and by the different nuances in the timbre, which the treble and the bass fingerboard have; the performer uses the options for dynamic outlining of the musical structure in the particular manual by choosing registers of higher density, etc.

But when differentiation of two ore more voices in one manual is needed - an inevitable situation in the more complex polyphonic forms, typical for the works in the repertoire of the students from the performance classes in the universities - the problem becomes acute.

This major issue is not treated in the current Bulgarian theoretical and methodological accordion literature. The more substantial Bulgarian theoretical works on the methodology of teaching the accordion are printed back in the 90-ies and are only three. In two of them (the methodology of G. Galabov and P. Marinov) the subject of the work on polyphonic material is not included at all. In the third one, this issue is touched with only two sentences by the author R. Poterov: "In cases of two or three voices, i.e. more than one in a given manual, the standing out of any of them is impossible. In such situation the only applicable approach is the articulation" „Когато има двуглас или триглас, т. е. повече от един глас в някой от мануалите, е невъзможно открояването на който и да е от тях. Тогава единственият начин, който остава, е артикулационният" [10, p. 113]. Unfortunately, the author does not specify what he means by "articulation approach".

It is know that in music theory the term "articulation" (from the Latin "Articulation" which means to stand out, to emphasize) applies both to the touché - the contact of the fingers with the keys (and in particular - to some of the strokes) and to the methods of fragmentation of musical texture in general - dynamic, expressional, of timbre. And if we substitute the Latin word "articulation" with "fragmentation" (standing out, emphasis) in the quotation above it would look like the following: "In cases of two or three voices, i.e. more than one in a given manual, the standing out of any of them is impossible. In such situation the only applicable approach is the fragmentation (the emphasis)". 
On the surface of it, the most obvious conclusion is that this author does not provide a solution to the problem, but such a conclusion is unjustified, if we assume that the author refers articulation to the touché only, i.e. to the finger articulation methods. In this case the author has to be counted among the supporters of the first of the two opposite articulation concepts, presented below - concepts which had been formed in the performance and educational practice of the accordionists, the dispute between them being still open. Each of them suggests its solutions of the described issue.

\section{First Articulation Concept}

The representatives of the first concept in Russia, for example, are the followers of Govorushko - Saint Petersburg Conservatory. On the questions of articulation in the interpretation of polyphonic works they are based on the organ articulation theory of Braudo, referring to the similarity of the sound-forming pattern of the accordion and the organ (in both instruments the main driver of the sound is the airflow, whose intensity cannot be individually adjusted for each key). This analogy will be presented in detail.

When playing the organ using one manual and in one register, the volume is also constant. How can the organ overcome this restriction? Braudo provides the following solution:

"The increase of the sounding part of the tone durations, indicated in the text, and the shortening of the caesuras between the tones, associated with it, leads to an increase of the volume of sound for a time unit. And vise versa - the decrease of the sounding part of the indicated durations and the extension of the caesuras leads to a decrease of the volume of sound. Those increases and decreases of the volume of sound can be perceived as amplification or attenuation of sonority. When the coherence of tones is gradually increased or decreased we gain the corresponding impression of crescendo or diminuendo. When the described articulation thickening runs in short waves it results in short crescendos, serving as accents." „Увеличение звучащей части обозначенных в тексте длительностей и связанное с этим сокращение размера цезур между тонами приводит к увеличению количества звучания в единицу времени. И обратно - уменьшение звучащей части обозначенных длительностей, увеличение цезур между тонами равносильно уменьшение количества звучания могут быть восприняты как усиление или ослабление звучности... При постепенном увеличении или уменьшении связаности тонов мы получим соответно впечатление постепенных crescendo и diminuendo. Если описанное артикуляционное сгущение будет происходить короткими волнами, мы получим короткие crescendo, производящие впечатление акцентов.” [4, р. 16].

In other words, according to Braudo, the volume of sound of the organ in the described case depends on the duration of the contact of the fingers with the keys.
By analogy, the supporters of this concept learn, that the bellows, just like with the organ, is supposed to provide an even and constant compression on the sources of sound, while the primary tool for accenting in the polyphonic texture should be the touché, or the finger articulation.

The dynamic construction should be made stepwise, without thinning of the particular detail using the bellows, which may interfere with the other elements of the texture. This is the reason why the intonation is based on tones, which cannot be developed dynamically from inside by the bellows. Those principles refer not only to the organ transcriptions, but are transferred to the polyphonic works in general, regardless of the fact that they had been originally written for other instruments.

This concept has its own advantages and reasonable grounds, but it contains certain failings.

If the organ's sonority can depend on the duration of the contact of the fingers with the keys within the framework of a given touch, as stated by Braudo, is this applicable to the accordion as well?

It is known that the tones of the accordion do not posses that rich variety of timbres as those of the organ. The overtones of the organ melt into the space more slowly, that those of the accordion. The sound of the accordion ceases almost instantly when with the even compression of the bellows the key closes the valve and stops the air flowing to the audio source (the acoustic advantages of the premises cannot solve this issue in general). That is why, if the method of Braudo is directly applied to the accordion articulation - as recommended by the supporters of that concept - one question still remains disputable, namely: to what extent the described articulation thickening will be perceived as amplification of sonority and wouldn't the articulation dilution lead to fragmentation of the perceivable caesuras, instead of attenuation.

Another way for emphasizing in the polyphonic texture with the means of pure finger articulation methods is the use of the so-called "partial touché". This effect can be achieved, according to Gvozdev, when "the key is not pressed to the bottom", but it is "partially pressed, to a certain level" „клавиша погружается в клавиатуру не до упора, а частично, до определенного предела" [8, p. 16], thus achieving a more quiet tone. But such a touché is hard to make, since it requires a very precise sense of that "certain level", beyond which the tone sounds impure, can be decreased by a semitone, especially in cases of intense dynamics. In the modern accordion music such a defect is turned into effect, called non-tempered glissando (in "Fleshing" by Arne Nordhime, "Alone" by Erkki Jookinen, "Sieben Worte" by Sofia Gubaidulina and many other).

The third and may be the most efficient way of accenting of the different melody lines "using the fingers" is to play the phrase-forming caesuras in the different voices which do not match in time. This method is very important not only for the accordionists - the best performers have always paid tribute to it. For example, Blumenfeld has considered it as "an important method for embossed voice-leading, not only in 
Bach's works, but in other styles as well" „важным средством для выпуклой передачи голосоведения, и при том не только в произведения Баха, но и в других стилях" [6, p. 99].

A fragment of Fantasie und Fuge in g-moll by J. S. Bach can be given as an example. In it, the phrase-forming caesuras are conditionally marked with „V” (Fig.1):

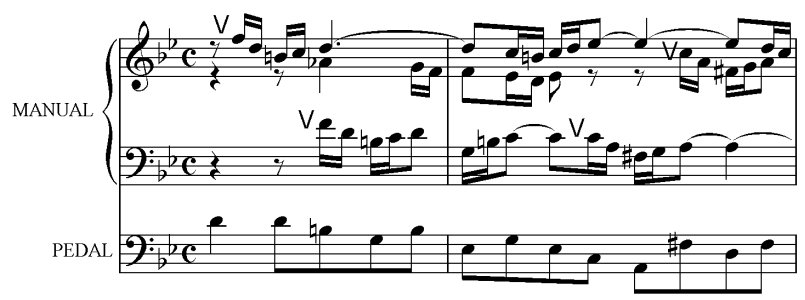

Figure 1. Fantasie und Fuge in g-moll by J. S. Bach.

\section{Second Articulation Concept}

The supporters of the second concept are based on the fact, that the articulation palette of the accordion is quite richer, compared to that of the organ or the piano, that is why it must not be so strictly limited in the polyphonic works, i.e. it must not be reduced to finger methods only.

In "Some Issues of the Theory of Bayan Performance" Y. Akimov says: "Unfortunately we have to point out, that there is no explorer and musicologist who has paid attention to the accordion when searching answers to questions from the theory of performance. If we compare the organ, the piano and the accordion from the viewpoint of articulation (i.e. the management of the sound), then we should give our preference to the last. Braudo, perhaps unaware of the existence of the accordion, highlights the advantages of such instruments, whose sound is subject to the performer's will in the entire course of the sounding: "The note, taken by the vocalist, is a whole palette of qualities and shades. The note vibrates, gets thinned and receives a nuance in its whole richness of dynamics and timbre... The processes of the life of the tone are also managed when it's being performed by any instrument, whose flowing sound is directly connected to the live human perceptions and may possess power and expression, competing with the human voice, with a note sung by a person." „С сожалением произходится отмечать, что ни один исследователь-музыковед, разрабатывая вопросы теории исполнительства, не имеет в виду баян. Между тем, если мы рассмотрим с точки зрения артикулирования (то есть управляемости звуком) орган, фортепиано и баян, то предпочтение надо будет отдать последнему. Браудо, быть может и не подозревая о существовании баяна, отмечает преимущество инструментов, на которых звук подчинен воле исполнителя на всем своем протяжении: „Нота, взятая вокалистом, - это целая гамма качеств и оттенков. Нота вибрирует, филируется, нюансируясь при этом в своих интонации, динамике, тембре... Историей тона, процессом жизни тона является, однако, и нота, взятая на любом инструменте, длящийся звук которого связан непосредственно с живым человеческим действованием и может обладать в силу этого выразительностью, состязающейся с человеческим возгласом, с пропетой человеком нотой." [13, p. 60].

It is obvious that the processes of alteration "inside the note" appear to be a substantial factor in music. And since the accordion is among those instruments, which can manage those processes thanks to the bellows, the supporters of the second concept prioritize the articulation by the bellows, for they think that the number of the means of articulation by the fingers without the active support of the bellows, is quite restricted. Within the framework, drawn by the character of the work and the requirements of the style and the genre, of course, those opportunities have to serve not as ways for imitation (of the organ, for example), but as accordion means, set to serve to the most complete expression of the musical content in the polyphonic works. Moreover, it is a fact that the organ articulation cannot serve as an etalon to be applied to all polyphonic works, not even to all of the works for organ.

Based on that, the representatives of the second concept allow a change, a development inside the different tones, which may be achieved by the bellows. The stepwise dynamic construction in places where the style and the architectonics of the work require it, does not exclude the finer shading of the detail by the bellows. Thus, even when the complex sonority is flat as a whole, it is characterized with better fluency and brighter dynamic and timbre colouring of the separate tones. Since the supporters of that concept regard the bellows as a main tool for embossed voice-leading, they advise the bellows to follow the theme when playing polyphonic works.

Both concepts described above have their assets and disadvantages.

For example, if we take their basic features as axiomatic principles - the management of the air compression by the bellows, the following question remains totally unanswered: having just one bellows and several voices that sound simultaneously (each of them with its independent logic and line of development) wouldn't we interfere with the other voices by "the bellows which follows the theme"? Or, for example - aren't the options for articulation with the fingers only (and even conduct of the bellows) quite insufficient and are they effective in all other cases?

It is true that no art can be born under the absolute adherence of the first, the second, and any other principles. To a great extend art is achieved when everything is used to measure and with flexibility, depending on the particular case and serving the certain aim - in general and in particular, at given moments of the musical development.

The accordion is not and cannot be an organ. It must not be forced into doing the organ's work at any cost. Any attempts at that lead to one an only outcome, called imitation or a fake substitute.

The facts, presented up to now, support the thesis that when playing transcripts the means of expression of the original instrument should not be mechanically transferred 
upon the accordion. The intention to search for an acoustic equivalent of the original sounding of the transcription does not always lead to an interpretation of any artistic value. In such cases the accordionist is supposed to use the means of his or hers instrument, subjected to the fullest re-creation of the music in the piece - not to the means of expression of another instrument. This should be done, of course, without crossing the borders of the original musical idea, the style or the genre identity.

More facts and examples will be given in support.

Here is what Snezhana Simeonova has written on the clavier inventions and symphonies of Bach: "The synthetic language of Bach requires a search for signs of other genres from his instrumental and vocal art in his clavier works." „Синтетичността на Баховия език ни задължава да търсим в клавирната му фактура белези на други жанрове от неговото инструментално и вокално-инструментално творчество.” [11, p. 7]. On that same page she refers to Druskin, according to whom "In Bach's clavier style one can clearly notice the "string-type" of the sound, which had been closer to the violin, than to the organ." „В фортепианном стиле Баха отчетливо видна "струнность" звучание, которое было ближе к скрипке, чем к органу." [7, p. 303]. He also makes a reference to Albert Schweitzer, who, in relation to that feature formulates the following principle: "In general we can define the principle, that every theme and passage of Bach has to be fragmented in such a way, as it is being played by e string instrument." „Изобщо може да се установи принципът, че у Бах всяка тема и всеки пасаж трябва да се разчленяват така, сякаш се изпълняват на щрайхов инструмент." [1, p. 279]. And finally - here is what Simeonova summarizes at the same place: "The association of a given work or parts of it with the sounding of another instrument, or with the human voice, is a starting point of direction to the performer. Following it he or her may start a quest of searching for particular means of realization of the idea." „Асоциирането на дадена творба или отделни нейни линии със звученето на друг инструмент или с човешкия глас е вече една насока за изпълнителя. По нея той може да тръгне в търсене на конкретни инструментални средства за реализиране на идеята.".

The difference between using the sounding of another instrument just as a "starting point" and the desire to achieve a blind imitation of that sounding is huge. Unfortunately, for a large part of the accordionists that difference does not exist. That is why their attempts to imitate, at all costs, the original instrument often lead to extremities, absolutely contradictory to the laws of acoustics of the instrument and the good sounding.

Such an extremity is the desire to imitate the piano in the clavier transcriptions by placing an excessive focus on the start of each tone, followed by an instant drop of the dynamics. For cases like this Fr. Lips notes that: "... sometimes articulation of that kind can be accepted as a particular sound ornamentation, ... but the blind imitation of the specifics of the piano is contradictory to the nature of our instrument." „Такое слепое подражание специфике рояля противоречит природе нашего инструмента. Вероятно, это иногда приемлемо, как особая динамическая краска.” [2, p. 59].

Another extremity is the requirement for "overlapping" the tones when performing in legato - which is recommended by certain teachers. In such cases the keys are being pressed "a little longer than needed", which according to them is an imitation of the organ reverberation. In the beginning of "Präludium und Fuge in e-moll" (from "Eight Short Preludes and Fugues for Organ" by J. S. Bach), along the gradual movement of melody, such style of performance leads to dissonant second overlaps at the start of each tone, which d not sound well and contrast to the calm and fluent theme of the fugue (Fig. 2):

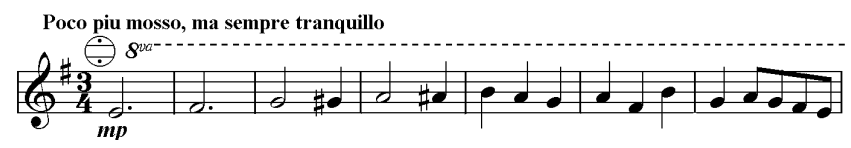

Figure 2. Präludium und Fuge in e-moll by J. S. Bach, Fuge

In this case an even flow from the bellows and the use of finger articulation only may lead to a still and dull sounding in piano, which will hardly touch anyone from the audience. That is why, a particular "extension" of each tone by the bellows - when done carefully and well-dosed, would enrich the timbre of each sound and bring life to it. On the other hand, immersing into excessive vocalization, over the boundaries of the relatively even sounding, would lead to a performance incompatible with the particular style.

In the fragment from „Toccata und Fuge in d-moll” by Bach the overlapping of tones leads to the impression of a "hampered" movement and the passage would sound "heavy" (Fig. 3):

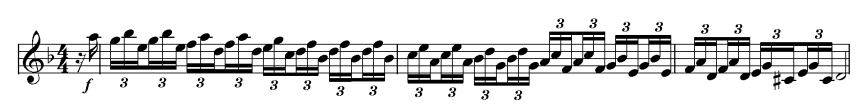

Figure 3. From „Toccata und Fuge in d-moll” by J. S. Bach

In this case the articulation by the bellows is inappropriate, even unrealizable. The constant and even air compression of the intense bellows is, in this case, very suitable, since it provides distinctness of the finger articulation. This, however, should not be applied to "Präludium und Fuge in e-moll" from "Eight Short Preludes and Fugues for Organ" whose calm and choral texture does not need such tension in the tone, but rather a decoration nuance by the bellows (Fig. 4):

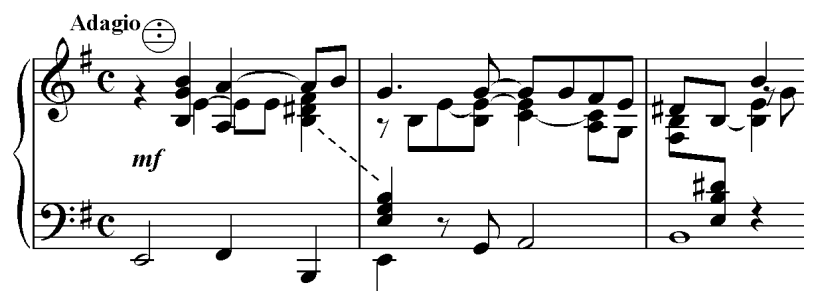

Figure 4. Präludium und Fuge in e-moll by J. S. Bach, Präludium 
Yet we have to point out that if this shading gets overdone, the result might be a quite romantic and alien to the style interpretation of the work, instead of the desired brighter toning.

Following is a brief description of some features, related to the dynamics, the register switches and bellows conduct, which have to be taken into account in the course of the work on polyphonic pieces.

\section{Dynamics, Register Switches, Bellows Conduct}

When polyphonic works are being dynamically shaped, the performer has to follow the general architectonic plan of each work. All the dynamic contrasts, the build-ups, the falls and the nuances, being fluent or stepwise to a different extent, should not be a goal in itself, but rather a natural result coming from the structure of the music texture and supporting the main music idea. They should carry the spirit of the composer, the age and the corresponding style.

For the works of Bach A. Schweitzer writes: "Both in the clavier works and in those for organ, piano and forte do not melt into one another unnoticeably. A certain volume level dominates in a whole period, after which another whole period stands out - having a different tonal decoration. "The music of Bach is always more or less inherent with magnificence. It is constructed of wide terraces, just like the Assyrian ancestral temples of humanity", writes Vianna da Motta in his article "For the Promotion of Bach's Works." „И в клавирните пиеси, както и в органните, пиано и форте не преливат незабелязано едно в друго. Известна сила на звука доминира в цял един период, след което ясно се откроява отново цялостен период с друга звукова окраска. „На Баховата музика винаги е присъщо повече или по-малко величие. Тя непрекъснато се гради на широки тераси като асирийските прастари храмове на човечеството”, пише Виана да Мота в своята статия „За популяризирането на Баховите клавирни произведения”. [1, p. 271]. This specific characteristic feature of the structure of Bach's thought requires its re-creation to be accomplished by a terraced dynamic build. The frequent effects of reverberation and the contrasting opposition of the theme in piano in a chapter to the theme in tutti in another chapter, are very typical for the Baroque. But in the contemporary polyphonic works the dynamic constructions usually run in a more fluent manner.

Except by the bellows, the dynamic constructions in the polyphonic works can also be achieved by complicating the texture. Adding more voices as layers leads to a natural enhancement of sonority, which does not require an additional dynamic emphasis by the bellows by all means.

In this relation the functions of the register switches are very important. Except that they change the timbre nuance thus facilitating the embossing of the music construction in a manual, they, on one hand, play a major role for the achievement of a dynamic balance between the two manuals, and on the other - support the dynamic re-creation of the architectonic build in the polyphonic work in general. We have to point out that when selecting them there is another characteristic feature that must not be neglected - besides the timbre and the volume, some of them change the octave group of the tones. Not considering that function of the register keys may negatively influence the logic of the voice conduct.

The bellows conduct faces a particularly difficult challenge with the polyphonic textures. The complexity comes form the fact that the places, appropriate for changing the direction of the bellows without having a fragmentation in some of the melodic lines, are often quite few in number. The non-matching caesuras in the separate voices and the different length of the phrases in each voice, as well as the long chains of legato tones in some of the voices, are all issues to the bellow conduct, especially when such a texture requires a legato performance. No matter how skillfully or fluently the direction of the bellows is being changed, the light interruption of the tone is always detected by the ear. That is why when working on each particular piece the performer has to very carefully analyze the bellows score in search of an optimal solution for distribution of the moves of the bellows, thus providing that the change of the direction of the bellows will not lead to sharp and coarse fragmentations of the polyphonic texture.

\section{Conclusions}

The analysis of the two articulation concepts, along with the presented facts and examples from the music theory and practice, allow the drawing of the following conclusions:

1. Each of the articulation concepts offers a different solution to the issue of emphasizing of the different layers and elements of the polyphonic texture in the accordion interpretation of transcriptions. The first sees it in the finger articulation, the second - in the bellows.

2. The solutions these concepts provide are contradictory when the main principle in any of them is being taken as an axiom.

3. In case they are not regarded as absolute, both the solutions have their advantages, on which the right choice of the means of expressions in accordion interpretation is based.

4. When playing polyphonic transcriptions the accordionist has to use the means of expression of his or her instrument - those means have to be subjected to the fullest re-creation of the music ideas, and not to be offered in service to those of another instrument, provided the performer sticks to the framework of the style and the genre identity.

5. The artistic value of the interpretation depends mainly on the measure and the flexibility with which those means are being used, depending on the particular occasion and dedicated to the service of the goal, which is set in general or in particular moments of the musical development.

In conclusion we may say that the subject of the work of 
the accordionists with polyphonic pieces is hardly covered in the literature. This subject is quite specific - its unclear and controversial moments yet to find their final answers in the methodology of the accordion and in the performers theory and practice. The issues, presented here, provide directions for subsequent wider and more extensive exploration in the fields of methodology of accordion education and performance art.

\section{References}

[1] Al. Schweitzer, "Johann Sebastian Bach". Sofia.1981; Ал. Швайцер, „Й. С. Бах”. София. 1981

[2] Fr. Lips, "The Art of Playing the Bayan". Moscow. 1985; Фp. Липс, „Искусство игры на баяне”. Москва. 1985

[3] G. Galabov, "Methodology of Accordion Education". Sofia. 1990; Г. Гълъбов, „Методика на обучението по акордеон”. София. 1990

[4] I. Braudo, "Articulation". Leningrad. 1973; И. Браудо, „Артикуляция”. Ленинград. 1973

[5] K. Fileva, "Methodology of Piano Education". Plovdiv. 2011; К. Филева, „Методика на преподаване на пиано”. Пловдив. 2011

[6] L. Barenboim, F. M. Blumenfeld, "Issues of the Art of Music Performance", vol.2. Msocow. 1958; Л. Баренбойм, Ф. М. Блуменфельд, „Вопросы музыкально-исполнительского искусства”, вып. 2. Москва. 1958
[7] M. Druskin, "Johann Sebastian Bach". Moscow. 1982; M. Друскин, „Йоганн Себастъян Бах”. Москва. 1982

[8] P. Gvozdev, "Principles of the Sound Forming of the Bayan and Its Sound Production". "Bayan and Bayan Perrformers". Moscow. 1970; П. Гвоздев, „Принципы образования звука на баяне и его извлечения”. Кн. „Баян и баянисты”. Москва. 1970

[9] P. Marinov, "Articles on Accordion Education". Plovdiv. 1996; П. Маринов, „Очерци за обучението по акордеон”. Пловдив. 1996

[10] R. Poterov, "Methodology of Accordion Education". Blagoevgrad. 1995; Р. Потеров, „Методика на обучението по акордеон". Благоевград. 1995

[11] S. Simeonova, "Johann Sebastian Bach. Inventions and Symphonies for Clavier. Specifics of the Performers' Approach". AKT Musik. Plovdiv. 1995; С. Симеонова, „Йохан Себастиан Бах. Инвенции и симфонии за клавир. Специфика на изпълнителския подход”. АКТ Musik. Пловдив. 1995

[12] Ts. Andreeva, "Methodology of Clavier Education". Sofia. 1985; Ц. Андреева, „Методика на клавирното обучение”. София. 1985

[13] Y. Akimov, "Certain Theoretical Issues in Playing the Bayan". Moscow. 1980; Ю. Акимов, „Некоторые проблемы теории исполнительства на баяне”. Москва. 1980 